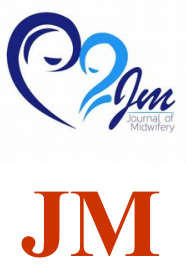

Volume 8 No. 2 (Oktober 2020)

(C) The Author(s) 2020

\title{
PEMBERIAN EDUKASI DAN PENDAMPINGAN KETIDAKNYAMANAN PADA NY."H" G2P1A0 DI PMB ERIKA KOTA BENGKULU
}

\section{PROVIDING EDUCATION AND MENTORING DISCOMPORT FOR MRS."H" G2P1A0 AT THE INDEPENDENTS PRACTICES OF THE MIDWIFE ERIKA OF BENGKULU CITY}

\author{
LASTRIANI, YETTI PURNAMA, LINDA YUSANTI \\ MAHASISWA PRODI D3 KEBIDANAN FAKULTAS MIPA, \\ UNIVERSITAS BENGKULU \\ PRODI D3 KEBIDANAN FAKULTAS MIPA, UNIVERSITAS BENGKULU \\ Email: ypurnama@unib.ac.id
}

\begin{abstract}
ABSTRAK
Pendahuluan: Ibu hamil TM III sering merasakan ketidaknyamanan seperti nyeri punggung bawah dan sering berkemih, saat bersalin ketidaknyamanan yang dirasakan yaitu nyeri persalinan dan salah satu ketidaknyaman pada masa nifas adalah pembengkakan payudara.. Penelitian ini bertujuan untuk melakukan asuhan kebidanan komprehensif pada Ny."H" G2P1A0 dengan pemberian edukasi dan ketidaknyamanan di PMB Erika Kota Bengkulu. Metode: Jenis penelitian ini adalah deskriptif dengan teknik observasi, wawancara, pemeriksaan fisik, studi dokumentasi dan kepustakaa. Hasil dan Pembahasan: Asuhan kebidananan komprehensif yang diberikan pada NY."H" di masa hamil adalah massase efflurage dan menganjurkan ibu untuk mengurangi minum pada malam hari. Pada saat bersalin asuhan yang diberikan adalah mobilisasi, kompres hangat dan dalam masa nifas dilakukan kompres daun kubis dingin untuk mengurangi nyeri dan pembengkakan pada payudara. Hasil pemberian edukasi dan pendampingan: kehamilan berjalan baik, persalinan berjalan secara spontan, bayi lahir sehat, masa nifas berjalan normal, tidak ada penyulit dan setelah 40 hari akan meggunakan alat kontrasepsi suntik 3 bulan. Kesimpulan: asuhan yang diberikan sesuai dengan kebutuhan subjek yang didukung oleh teori dan evidance base dalam kebidanan. Asuhan selama 7 minggu berjalan lancar dan normal.
\end{abstract}

Kata Kunci: Edukasi, Pendampingan, Ketidaknyamanan

\begin{abstract}
Intoduction: TM III pregnant women often feel discomfort such as low back pain and frequent urination, during childbirth the discomfort is labor pain and one of the discomforts during the puerperium is breast engorgement. This study aims to provide comprehensive obstetric care for Mrs. "H" G2P1A0 at independents practices of the midwife of Bengkulu City. Method: This
\end{abstract}


type of research is descriptive with observation, interview, physical examination, documentation and literature study. Result and Discussion: Comprehensive obstetric care given to NY. "H" during pregnancy is massase efflurage and encourages mothers to reduce drinking at night. During childbirth, the care given is mobilization, warm compresses and during the puerperium a cold compress of leaves is done to reduce pain and swelling in the breasts. The results of education and assistance are: pregnancy is going well, labor is spontaneous, the baby is born healthy, the postpartum period runs normally, there are no complications and after 40 days will use 3 months of injection contraception. Conclusion: care provided in accordance with the needs of the subject supported by theory and evidance base in midwifery. Care for 7 weeks went smoothly and normally.

\section{Keywords: Education, Assistance, Discomfort}

\section{PENDAHULUAN}

Proses kehamilan pada perempuan adalah salah satu proses yang alamiah. Selama kehamilan mengakibatkan banyaknya perubahan pada ibu hamil, baik perubahan secara fisik maupun psikologis yang akan menyebabkan munculnya keluhan-keluhan pada ibu hamil seperti nyeri punggung bawah, dan peningkatan frekuensi berkemih dirasakan saat ingin tidur malam hari sehingga menggangu waktu tidur pada saat malam hari. Dampak nyeri punggung bawah pada ibu hamil adalah ibu akan mengalami gangguan tidur yang menyebabkan keletihan dan iritabilitas serta ketidaknyamanan dalam melakukan aktivitas. Salah satu cara untuk mengatasi nyeri punggung bawah pada ibu hamil adalah senam hamil dan massase pada daerah punggung bagian bawah.

Hasil penelitian Megasari (2015), menunjukan bahwa didapatkan hasil dari 21 orang ibu yang melakukan senam hamil seluruhnya tidak mengalami nyeri punggung bawah yaitu sebanyak 21 orang (100\%), sedangkan dari 26 orang ibu yang tidak melakukan senam hamil ada 16 orang $(61,5 \%)$ yang mengalami nyeri punggung bawah, artinya ada hubungan yang signifikan antara senam hamil dengan nyeri punggung, sedangkan berdasarkan penelitian setiawati (2019) menunjukkan bahwa nyeri punggung bawah pada ibu hamil diberikan teknik massage effleurage mampu menurunkan nyeri punggung bawah pada ibu hamil. Beberapa cara untuk mengurangi frekuensi berkemih diantaranya kosongkan kandung kemih ketika ada dorongan, perbanyak minum pada siang hari, engurangi minum pada saat malam hari.

Ketidaknyamanan yang terjadi pada ibu bersalin diantaranya nyeri persalinan. Nyeri persalinan merupakan nyeri yang kompleks, sensasi tidak enak/rasa sakit selama persalinan yang disebabkan kontraksi uterus, tekanan pada serviks, kandung kemih dan usus oleh bagian terendah janin, peregangan dari jalan lahir dan vagina, posisi janin, aliran darah miometrial, proses peradangan dari otot uterus, aspek psikologis dan kontraksi uterus bawah serta kondisi isometrik tertentu. Rasa nyeri saat bersalin dapat menimbulkan rasa khawatir, tegang dan kecemasan.

Efek nyeri apabila rasa nyeri terlalu berlebihan akan mengakibatkan stress, jika stress berkelanjutan maka berdampak pada persalinan yang berpengaruh pada hormon oksitosin yang menyebabkan kontraksi tidak adekuat sehingga menjadikan persalinan lama dan fetal distress atau asfiksia (bayi berwarna kebiruan). Salah satu cara dari metode non farmakologis untuk mengurangi nyeri persalinan berdasarkan teori Gate Control dapat dilakukan melalui mobilisasi, tehnik relaksasi nafas, kompres dan pendampingan persalinan.

Hasil penelitian Purnama (2018), tentang pengaruh penggunaan kursi persalinan BCMK15 terhadap intensitas nyeri persalinan pada multipara dimana kursi persalinan BCMK15 akan memfasilitasi perubahan posisi pada ibu bersalin, menunjukkan bahwa 
terdapat pengaruh kursi persalinan BC-MK15 terhadap intensitas nyeri ibu bersalin post 3 (pembukaan $10 \mathrm{~cm}$ ) dan hasil penelitian Purnama (2019) tentang pengaruh posisi tegak terhadap intensitas nyeri persalinan menunjukkan bahwa posisi tegak dapat mengurangi nyeri persalinan dengan memfasilitasi perubahan posisi setiap tahapan dalam proses persalinan yang menimbulkan relaksasi dan menurunkan persepsi nyeri sehingga tercipta peningkatan rasa nyaman pada ibu bersalin. Hasil penelitian Felina (2015), menunjukkan bahwa terdapat pengaruh pemberian kompres panas dan dingin terhadap menurunkan derajat nyeri persalinan kala I fase aktif. Hasil penelitian novita (2017) adanya pengaruh teknik relaksasi nafas dalam terhadap respon nyeri pada ibu inpartu kala I fase aktif. Hasil penelitian Adam (2015), menunjukkan bahwa terdapat hubungan yang bermakna antara pendampingan suami dengan intensitas nyeri persalinan kala I fase aktif.

Ketidaknyamanan yang terjadi pada masa nifas adalah nyeri setelah melahirkan dan pembengkakan payudara. Intensitas kontraksi uterus meningkat secara bermakna setelah persalinan bayi, yang merupakan respon segera untuk mengurangi jumlah volume intra uterus. Kontraksi uterus ini terjadi secara fisiologis dan menyebabkan nyeri yang dapat mengganggu kenyamanan ibu di masa setelah melahirkan. Penanggulangan nyeri pada masa nifas sangat penting karena dapat memperbaiki keadaan fisiologi dan psikologi. Salah satu cara metode nonfarmakologis yang dapat dilakukan untuk mengatasi nyeri pada masa nifas antara lain mengubah posisi tubuhnya menjadi telungkup dengan meletakkan bantal atau gulungan selimut di bawah abdomen, memberikan terapi pemijatan pada ibu yang disebut massase dan kompres daun kubis dingin untuk mengurangi nyeri dan pembengkakan payudara.

Hasil penelitian Dewiani (2018) menunjukkan bahwa terdapat pengaruh penggunaan kompres daun kubis dingin terhadap penurunan intensitas nyeri dan pembengkakan payudara pada ibu post partum.

Berdasarkan survey awal yang penulis lakukan di PMB Erika kota Bengkulu, pada tahun 2019 tercatat 153 ibu hamil. Ny. "H" $\mathrm{G}_{2} \mathrm{P}_{1} \mathrm{~A}_{0}$ hamil 35 minggu mengeluh nyeri punggung bagian bawah sejak umur kehamilan 8 bulan yang lalu, nyeri terasa seperti nyut-nyutan, nyeri timbul ketika beraktifitas serta sulit untuk memulai tidur dan merasa tidurnya kurang nyenyak karena nyeri punggung bagian bawah.

Berdasarkan gambaran umum kasus, maka penulis merasa sangat perlu untuk melakukan asuhan kebidanan berkesinambungan (COC). COC merupakan pelayanan kebidanan continue yang dimulai sejak masa kehamilan, persalinan asuhan kebidanan pada neonatus, hingga perencanaan keluarga berencana.

\section{METODE PENELITIAN}

Penelitian ini merupakan penelitian deskriptif dengan studi penelaan kasus (case study) intrumen yang digunakan yaitu pedoman observasi, wawancara, pemeriksaan fisik, studi dokumentasi dan kepustakaan sesuai dengan KEPMENKES Nomor 938/Menkes/SK/VII/2007 mulai dari kehamilan TM III, bersalin, bayi baru lahir dan masa nifas. Subjek penelitian adalah NY. "H" G2P1A0. Waktu penelitian mulai tanggal 11 Maret sampai 27 April 2020.

\section{HASIL PENELITIAN}

Asuhan kebidanan pada masa kehamilan pada Ny."H" umur 33 tahun G2P1A0 di PMB Erika kota Bengkulu tanggal 11 Maret 2020 didapatkan keluhan ketidaknyamanan pada masa kehamilan Ibu mengeluh nyeri punggung bawah sejak usia kehamilan 32 minggu, serta ibu sering kencing sejak usia kehamilan 37 minggu. Dilakukan pemeriksaan tanda-tanda vital dan pemeriksaan fisik dalam batas normal. Asuhan yang diberikan mendiskusikan nyeri punggung yang dirasakan oleh ibu adalah hal 
yang normal, Mendiskusikan dan menganjurkan senam hamil dan massase effleurage dan menganjurkan ibu untuk melakukan secara rutin dirumah. Mendiskusikan kepada ibu bahwa sering buang air kecil (BAK) yang dirasakan oleh ibu termasuk normal terjadi pada kehamilan TM III dan mendiskusikan untuk mengurangi minum pada malam hari. Setelah diberikan asuhan keluhan nyeri punggung bawah dan sering BAK berkurang.

Asuhan kebidanan pada masa bersalin, kala I tanggal 15 April 2020, ny."H" mengatakan mules-mules dan nyeri perut bagian bawah menjalar ke punggung bagian bawah serta sudah keluar lendir bercampur darah. Dilakukan pemeriksaan tanda-tanda vital dalam batas normal, hasil periksa dalam Portio : tipis penipisan $60 \%$, Pembukaan : 6 $\mathrm{cm}$, ketuban : $(+)$, presentasi : kepala, petunjuk : UUK kanan depan, hodge : II+, tidak ada molase. Asuhan yang diberikan yaitu mobilisasi, tehnik relaksasi nafas dalam, kompres hangat dan menghadirkan pendamping persalinan. Asuhan pada kala II, III dan IV dilakukan asuhan persalinan normal dan observasi 2 jam pertama. Proses persalinan berjalan lancar dan normal.

Asuhan kebidanan pada bayi baru lahir (BBL) pada By.Ny"H" yaitu melakukan penanganan BBL normal, menjaga kehangatan, melakukan pemotongan tali pusat, melakukan IMD, memberikan salf mata, Vit.K dan imunisasi HB-0 serta pengukuran antropometri. Bayi lahir normal dan tidak ada kelainan.

Asuhan kebidanan pada masa Nifas Ny.'H" dilakukan sejak 6 jam postpartum, asuhan yang diberikan melakukan pemeriksaan tanda-tanda vital, pengeluaran lochea dan TFU dalam batas normal. Pada kunjungan ke 2 ibu mengeluh nyeri payudara dan tampak ada pembengkakan pada payudara sebelah kanan. Asuhan yang diberikan menjelaskan dan melakukan pengurangan rasa nyeri pembengkakan payudara dengan kompres daun kubis dingin. Mendiskusikan pada ibu tentang tanda bahaya masa nifas, tanda bahaya pada BBL, memberikan penkes pemenuhan nutrisi bayi dan perawatan tali pusat memberikan ASI ekslusif pada bayinya dan minimal memberikan ASI setiap 2 jam sekali atau sesuai kebutuhan bayi. Memberikan penkes pada ibu tentang kebutuhan ibu pada masa nifas apakah ibu sudah memenuhi nutrisi, hidrasi, personal hygine, istirahat, menganjurkan ibu mengkonsumsi makanan yang bergizi, mengajarkan teknik dan posisi menyusui yang baik dan benar, Memberikan konseling dan mengajarkan ibu cara perawatan payudara. Pada kunjungan ke 3 Menjelaskan kepada ibu pada ibu dan suami tentang alat kontrasepsi.

Masa nifas berjalan normal, nyeri dan pembengkakan payudara berkurang, ASI lancar dan setelah 6 minggu post partum ibu memilih alat kontrasepsi suntikan 3 bulan.

\section{PEMBAHASAN}

Asuhan kebidanan pada masa kehamilan Ny. "H" merasakan keluhan ketidaknyamanan pada masa kehamilan Ibu mengeluh nyeri punggung bawah sejak usia kehamilan 32 minggu, serta ibu sering kencing sejak usia kehamilan 37 minggu. Teori mengatakan nyeri punggung bawah adalah masalah muskuloskeletal yang signifikan selama kehamilan yang berpotensi memengaruhi kualitas wanita secara negatif. Struktur ligementum dan otot tulang belakang bagian tengah dan bawah mendapat tekanan berat, Salah satu ketidaknyamanan yang dialami oleh ibu hamil trimester III adalah sering buang air kecil. Pada waktu hamil, ginjal bekerja lebih berat dari biasanya, karena organ tersebut harus menyaring volume darah lebih banyak dibanding sebelum hamil dan Kemudian janin dan plasenta yang membesar juga memberikan tekanan pada kandung kemih, sehingga menjadikan ibu hamil harus sering ke kamar kecil untuk buang air kecil.

Asuhan yang diberikan mendiskusikan nyeri punggung yang dirasakan oleh ibu 
adalah hal yang normal penyebab nyeri punggung bawah yang dirasakan ibu dikarenakan pada kehamilan adanya pelunakan ligamen dan sendi lumbosacrum sebagai tambahan pada peningkatan kadar hormon progesteron dan relaxin serta karena kepala bayi mulai turun ke pintu atas panggul mencari jalan untuk keluar.

Mendiskusikan dan menganjurkan senam hamil dan massase effleurage dan melakukannya secara rutin dirumah. Sebelum dilakukan asuhan senam hamil dan massase effluarage ibu mengalami nyeri punggung bawah setelah melakukan aktifitas serta gangguan pada tidur dan setelah dilakukan asuhan senam hamil dan massase effluarage nyeri punggung yang dirasakan ibu berkurang. Hal ini sesuai dengan hasil penelitian Megasari (2015) menunjukkan bahwa ada pengaruh senam hamil pada ibu hamil TM III, menunjukkan bahwa ada hubungan yang signifikan antara senam hamil dan nyeri punggung. Hal ini sesuai dengan hasil penelitian Setiawati (2019) menunujukkan bahwa pemberian massage effluarage dapat menurunkan skala nyeri punggung pada ibu hamil trimester III.

Mendiskusikan kepada ibu bahwa sering buang air kecil (BAK) yang dirasakan oleh ibu termasuk normal dikarenakan kepala janin turun ke dalam ruang panggul dan menekan kembali kandung kemih sehingga rasa ingin buang air kecil ibu meningkat, serta menjelaskan kepada ibu cara mengurangi ketidaknyamanan sering BAK adalah dengan cara mengurangi minum sebelum tidur, setelah mengurangi minum pada saat sebelum tidur keluhan sering kencing pada malam hari berkutrang dan ibu tidur lebih nyenyak. Menurut teori mengurangi minum sebelum tidur, kosongkan kandung kemih ketika ada dorongan, perbanyak minum pada siang hari, hindari minum kopi atau teh, berbaring miring kiri saat tidur dapat mengurangi keluhan sering BAK pada ibu hamil.

Asuhan kebidanan pada masa bersalin Persalinan kala I Ny."H" mengatakan mulesmules dan nyeri perut bagian bawah menjalar ke punggung bagian bawah serta sudah keluar lendir bercampur darah. Teori mengatakan nyeri persalinan disebabkan kontraksi uterus, tekanan pada serviks, kandung kemih dan usus oleh bagian terendah janin, peregangan dari jalan lahir dan vagina, posisi janin, iskemi uterus, aliran darah miometrial, proses peradangan dari otot uterus, aspek psikologis, tekanan pada ujung syaraf, tegangan pada jaringan dan persendian serta hipoksia otot uterus selama dan setelah kontraksi yang panjang. Berdasarkan teori keluhan yang sering dirasakan ibu bersalin yaitu dimulai dengan adanya his yang dipengaruhi oleh hormon estrogen dan progesteron, selanjutnya keluar lendir bercampur darah terjadi karena adanya pembuluh darah yang pecah akibat pembukan servik. Asuhan yang diberikan yaitu mobilisasi, tehnik relaksasi nafas dalam, kompres hangat dan menghadirkan pendamping persalinan. Setelah dilakukan asuhan dan tindakan tresebut ibu merasa lebih tenang dan rasa nyeri sedikit berkurang. Perubahan posisi setiap tahapan dalam proses persalinan yang menimbulkan relaksasi dan menurunkan persepsi nyeri sehingga tercipta peningkatan rasa nyaman pada ibu bersalin.

Teknik relaksasi nafas dalam dengan menganjurkan ibu untuk menarik nafas dalam lewat hidung dan menghembuskannya melalui mulut adanya pengaruh teknik relaksasi nafas dalam terhadap respon nyeri pada ibu inpartu kala I fase aktif.

Melakukan dan mengajarkan kompres air hangat yang diberikan pada bagian punggung ibu di area tempat kepala janin menekan tulang belakang kepala akan mengurangi nyari, karena akan meningkatkan sirkulasi ke area tersebut sehingga memperbaiki anoksia jaringan yang disebabkan oleh tekanan. pendamping persalinan memberikan pengaruh pada ibu bersalin karena dapat membantu ibu saat persalinan serta dapat memberikan perhatian, rasa aman, nyaman, semangat, menentramkan hati ibu, mengurangi ketegangan ibu Memberikan kompres hangat dengan suhu $38^{\circ} \mathrm{C}-40^{\circ} \mathrm{C}$ selama 20 menit. Setelah dilakukan kompres hangat nyeri 
persalinan berkurang. Hal ini sesuai dengan penelitian Felina (2015), menunjukkan bahwa adanya pengaruh kompres panas terhadap penurunan nyeri persalinan kala I fase aktif.

Pendamping persalinan memberikan pengaruh pada ibu bersalin karena dapat membantu ibu saat persalinan serta dapat memberikan perhatian, rasa aman, nyaman, semangat, menentramkan hati ibu, mengurangi ketegangan ibu. Hal ini sesuai dengan penelitian Adam (2015) menunjukkan bahwa pendampingan suami terdapat hubungan yang bermakna dengan intensitas nyeri persalinan kala I fase aktif.

Kala II Ny. "H" mengatakan nyeri semakin sering dan kuat seperti ingin $\mathrm{BAB}$ serta ada dorongan untuk meneran dan ada cairan yang keluar dari jalan lahir. Menurut teori adanya pengeluaran lendir yang bercampur dengan darah, dorongan untuk meneran, vulva membuka, dan perineum menonjol. Asuhan yang diberikan dengan memberikan motivasi agar ibu semangat meneran, mengatur posisi meneran dan menolong persalinan sesuai asuhan persalinan normal.

Kala III Ny. "H" mengatakan senang karena bayinya telah lahir dengan selamat tetapi ibu merasa sedikit lelah dan perutnya masih mules. Kala III adalah waktu untuk pelepasan dan pengeluaran plasenta. Setelah kala III berlangsung tidak lebih dari 30 menit, kontraksi uterus berhenti sekitar 5-10 menit. dilakukan manajemen aktif kala III yang meliputi penyuntikkan oksitosin 10 IU dalam waktu 1 menit setelah bayi lahir, melakukan penegangan tali pusat terkendali, melahirkan plasenta dilakukan dengan gerakan dorsokranial, membantu lahirnya plasenta dengan memilin plasenta searah jarum jam, massase fundus uteri, dan memastikan bahwa uterus berkontraksi dengan baik, mengecek kelengkapan selaput dan kotiledon plasenta, serta mengevaluasi apakah ada laserasi jalan lahir. Kala IV yaitu melakukan observasi 2 jam pertama. Berdasarkan teori melakukan observasi karena perdarahan postpartum paling sering terjadi pada 2 jam pertama. observasi dilakukan meliputi: tingkat kesadaran, pemeriksaan tanda-tanda vital yaitu tekanan darah, nadi, dan pernafasan, kontraksi uterus, terjadinya perdarahan, perdarahan masih dianggap normal bila jumlahnya tidak melebihi 400-500 cc. ${ }^{(1,14)}$

Asuhan kebidanan pada bayi baru lahir Asuhan yang diberikan pada bayi Ny. "H" yaitu memberikan salep mata untuk pencegahan infeksi, pemberian Vit $\mathrm{K}$ (phytomenadione) dosis $1 \mathrm{mg}$, memberikan imunisasi $\mathrm{Hb}-0$ dengan diosis $0,5 \mathrm{ml}$ setelah 1-2 jam pemberiaan Vit $\mathrm{K}$, menjaga kehangan bayi dan memberikan pada ibu untuk diberikan ASI. Pencegahan infeksi mata dianjurkan menggunakan salep mata antibiotik tetrasiklin $1 \%$, pemberian Vit $\mathrm{K}$ untuk pencegahan perdarahan pada bayi, pemberian imunisasi hepatitis $\mathrm{B} 0 \quad 0,5 \mathrm{ml}$ bermanfaat untuk mencegah infeksi hepatitis B terhadap bayi.

Asuhan kebidanan pada masa nifas Pada masa nifas kunjungan ke $2 \mathrm{Ny."H}$ " mengeluh nyeri dan pembengkakan pada payudara sebelah kanan. Asuhan yang diberikan yaitu menjelaskan dan melakukan pengurangan rasa nyeri pembengkakan payudara dengan kompres daun kubis dingin. Melakukan dan mengajarkan ibu tehnik pengurangan rasa nyeri pada payudara dengan menggunakan daun kuis dingin dengan cara meletakkan daun kubis dingin disekitar payudara yang bengkak lakukan selama 20-30 menit daun kubis salah satu tanaman yang memiliki kandungan asam amino glutamin daun kubis terbukti mengurangi bengkak pada bendungan ASI. setelah beberapa kali dilakukan kompres daun kubis keluhan nyeri pembengkakan pada payudara berkurang. Hal ini sesuai dengan penelitian Dewiani (2018) menunjukan bahwa kompres kubis dingin terdapat pengaruh menurunkan intensitas nyeri dan pembengkakan payudara pada ibu post partum.

Mendiskusikan pada ibu tentang tanda bahaya masa nifas, tanda bahaya pada BBL, memberikan penkes pemenuhan nutrisi bayi dan perawatan tali pusat memberikan ASI 
ekslusif pada bayinya dan minimal memberikan ASI setiap 2 jam sekali atau sesuai kebutuhan bayi. Teori mengatakan pada bayi yang baru lahir akan menyusu lebih sering, rata-rata adalah 10-12 kali menyusu tiap 24 jam atau bahkan 18 kali. Menyusui on demand adalah menyusui kapanpun bayi meminta atatu dibutuhkan oleh bayi (akan lebih banyak dari rata-rata menyusu). Menyusui on demand merupakan cara terbaik untuk menjaga produksi ASI tetap tinggi dan bayi tetap kenyang. Bayi mendapat manfaat yang besar dari ASI. Selain memberikan nutrisi terbaik yang dibutuhkan bayi, ASI juga berperan penting dalam melindungi dan meningkatkan kesehatan bayi. Pada hari pertama pada kondisi normal produksi kolostrum sekitar 10-100 cc dan terus meningkat setiap hari sampai sekitar 150-300 cc $\mathrm{ml} / 24$ jam. Kolostrum lebih banyak mengandung protein dibandingkan dengan ASI matur, tetapi kadar karbohidrat dan lemak lebih rendah. Selain itu, mengandung zat antiinfeksi 10-17 kali lebih banyak dibandingkan ASI matur.

Memberikan penkes pada ibu tentang kebutuhan ibu pada masa nifas apakah ibu sudah memenuhi nutrisi, hidrasi, personal hygine, istirahat, menganjurkan ibu mengkonsumsi makanan yang bergizi, mengajarkan teknik dan posisi menyusui yang baik dan benar, Memberikan konsling dan mengajarkan ibu cara perawatan payudara.. Teori mengatakan kesempatan yang baik untuk memberikan berbagai penyuluhan dan pendidikan kesehatan yang diperlukan ibu nifas. Seperti mengajarkan cara merawat bayi, cara menyusui yang benar, cara merawat jahitan, senam nifas, memberikan pendidikan kesehatan yang diperlukan ibu seperti gizi, istirahat, dan kebersihan diri.

Menjelaskan kepada ibu pada ibu dan suami tentang macam-macam KB yaitu KB suntik, IUD, pil, kondom, implant yang akan dipakai setelah masa nifas serta keuntungan dan efek samping dari masih-masing jenis KB. Setelah diberikan penkes ibu merencanakan akan menggunakan alat $\mathrm{KB}$ suntik 3 bulan. Hal ini sesuai dengan teori bahwa KB suntik 3 bulan cocok untuk ibu yang baru melahirkan dan sedang menyusui.

\section{KESIMPULAN}

Berdasarkan hasil asuhan kebidanan komprehensif pada NY."H" G2P1A0 adalah asuhan yang diberikan sesuai dengan kebutuhan klien yang didukung oleh teroi dan evidance based dalam pelayanan kebidanan. Asuhan selama 7 minggu berjalan lancar dan normal.

\section{SARAN}

Pentingnya pemeriksaan antenatal untuk mengetahui komplikasi secara dini dengan memeriksakan secara rutin ke tenaga kesehatan dan klien dapat mengaplikasikan cara mengatasi ketidaknyamanan yang dirasakan sehingga ibu dapat melewati masa kehamilan, bersalin, dan nifas dengan nyaman.

\section{DAFTAR PUSTAKA}

Adam J, Umboh J. Hubungan antara umur, parietas dan pendampingan suami dengan intensitas nyeri persalinan kala I fase aktif deselarasi di ruang bersalin RSUD PROF.Dr.H.Aloei saboe kota Gorontalo. Artikel penelitian. 2015;5(2):406-413. [diunduh 15-02-2020] Tersedia dari URL https://ejournal.unsrat.ac.id/index.php/jik $\mathrm{mu} /$ article/view/7464

Anwar M, Ali B, R. Prajitno P. 2018. Ilmu kandungan. Edisi Ke-3. Jakarta : PT Bina Pustakan Sarwono Prawiroharjo

Astutik., R.Y. 2014. Payudara dan laktasi. Jakarta: Salemba Medika

Dewiani K, Yetti P. Pengaruh kompres daun kubis dingin teradap penurunan intensitas nyeri dan pembengkakan payudara pada ibu postpartum. Jurnal kesehatan muhammadiyah bengkulu. 2018;02(06):488-493. [diunduh 23-012020] Tersedia dari URL : http://unmuhbengkulu.net/ojs/index.php/k eperawatan 
Felina M, Masrul, Detty I. Pengaruh kompres panas dan dingin terhadap penurunan nyeri kala I fase aktif persalinan fisiologis ibu primipara. Artikel kesehatan. 2015;4(1):58-[diunduh 23-01-2020] Tersedia dari URL http://jurnal.fk.unand.ac.id/index.php/jka/ article/viewFile/190/185

Hani, U, Jiarti K, Marjati, Rita Y. 2017. Asuhan kebidanan pada kehamilan fisiologis. Jakarta : Salemba Medika.

Lowdermilk DL, Perry SE, Cashion K, Alden KR. Maternity \& women health care; 2013.

Manuaba, Chandradinata IA. 2016. Ilmu kebidanan dan $\mathrm{KB}$ untuk pendidikan bidan. Jakarta: EGC

Megasari, M. Hubungan senam hamil dengan nyeri punggung pada ibu hamil trimester III. Jurnal kesehatan komunitas. 2015;1(3)17-20. [diunduh 20-01-2020] Tersedia dari URL http://jurnal.htp.ac.id/index.php/keskom/a rticle/view/95

Novita KR, Rompas S, Bataha Y. Pengaruh teknik relaksasi nafas dalam terhadap respon nyeri pada ibu inpartu kala i fase aktif di puskesmas bahu kota Manado. 2017;1(5). E-journal Keperawatan. [diunduh 20-06-2020] Tersedia dari URL : https://ejournal.unsrat.ac.id/index.php/jkp/ article/download/15894/15407.

Purnama Y, Johanes CM, Herry H. The effect of the bC-MK15 birth chair on the labor pain intensity in muktipara. Global medical dan health communication. 2018;6(3);61-155. [diunduh 17-01-2020] Tersedia dari URL https://pdfs.semanticscholar.org/710a/ffb1 40aafc8effa48e8950d11c8edec2394e.pdf

Purnama Y, Kurnia D. Pengaruh posisi tegak terhadap intensitas nyeri persalinan pada primipara di bidan praktik mandiri (BPM) Kota Bengkulu. Journal of midewifery 2019;1(7):52-59. [diunduh 14-01-2020] Tersedia dari URL https://jurnal.unived.ac.id/index.php/JM/a rticle/view/739

Rustikayanti, RN, Ira K, Yanti H. Perubahan psikologis pada ibu hamil trimester III. Journal-aipkind. 2016; 1(2): 47-45. [diunduh 18-01-2020] https://doi.org/10.36749/seajom.v2il.66

Saifuddin AB. 2016. Ilmu kebidanan. Edisi ke-4. Jakarta : PT Bina Pustakan Sarwono Prawiroharjo

Sari DP, Zurfa R, Sri WP. 2018. Nyeri persalinan. Mojokerto : Stikes majapahit Mojokerto

Setiawati I. Efektivitas teknik massage effleurage dan teknik relaksasi terhadap nyeri punggung pada ibu hamil trimester III. Jurnal akeskh jogja. 2019;1(1):1-7. [diunduh 20-01-2020] Tersedia dari URL : https://jurnal.akeskhjogja.ac.id

Sukma F, Hidayati, E, Jamil. 2017. Buku ajar asuhan kebidanan pada ibu nifas. Fakultas kedokteran dan kesehtan Universitas Muhamaddiyah : Jakarta. 